Malina Barcikowska

Polski Instytut Studiów nad Sztuką Świata, Warszawa

ORCID: 0000-0002-2231-2713

e-mail: mbarcikowska76@wp.pl

\title{
Sztuka i mit a "tożsamość kryzysowa” w hermeneutyce Hansa-Georga Gadamera
}

DOI: http://dx.doi.org/10.12775/RF.2019.043

Powinowactwo mitu i filozofii widoczne jest zwłaszcza $u$ jej początków. Rola hermeneutyki pozostaje dla tej problematyki szczególna źródeł można upatrywać w wysiłku interpretacji mitów. Jak zauważa Jean Grondin, „rozumienie musiało zmierzyć się z pojawieniem się coraz bardziej gorszących wątków pochodzących z religijno-mitycznego przekazu tradycji"1. W miejsce dosłownego odbioru mitycznych historii w pewnym momencie wkroczyła bardziej wysublimowana niż literalna próba ich tłumaczenia, którą można nazwać wysiłkiem hermeneutycznym. Filozofia Hansa-Georga Gadamera żywi dla mitów duży szacunek - filozof nazywa je „wyjaśnieniem wszechrzeczy”, „zbiornikiem wszelkiej wiedzy"2 i podobnie jak im hermeneutyce przyświeca ideał uniwersalności. W swojej pracy Gadamer bezpośrednio - lub w sposób bardziej ukryty - wykorzystuje zarówno konkretne mity starożytne, jak i specyficzne znaczenia, jakie można im przypisać. Uważam, że zgodnie z przedstawioną przez filozofa interpretacją pojęcie mitu może być istotne także dla zrozumienia kształtu, w jakim manifestują się hermeneutyczne tożsamości artysty, odbiorcy sztuki, uczestnika wydarzenia artystycznego czy tożsamość performera.

${ }^{1}$ Jean Grondin, Wprowadzenie do hermeneutyki filozoficznej, przeł. Leszek Łysień (Kraków: Wydawnictwo WAM, 2007), 35.

2 Hans-Georg Gadamer, „Problem dziejów w nowszej filozofii niemieckiej”, przeł. Krzysztof Michalski, w: Hans-Georg Gadamer, Rozum, słowo, dzieje (Warszawa: Państwowy Instytut Wydawniczy, 2000), 34. 


\section{Kryzys, regres i mit}

Czas powstania hermeneutyki filozoficznej utożsamia się z okresem kryzysu kultury Zachodu. Lilianna Bieszczad w książce Kryzys pojęcia sztuki zauważa, że myśl Gadamera wpisuje się w nurt przemian zachodzących w sztuce od końca XIX wieku do czasów współczesnych filozofowi. Jako taka jest ona "głosem estetyki, która musiała się określić, aby zdiagnozować, czy pojawi się nowy paradygmat" ${ }^{3}$. Kryzys, jak pisał Reinhart Koselleck w latach 60. XX wieku, diagnozując zjawiska równoległe do czasów powstania Prawdy i metody, jest wstrząsem, przełomem związanym z gwałtownymi przemianami także w sferze wartości, który powoduje utratę poczucia zadomowienia wśród doświadczających go ludzi ${ }^{4}$. W dziedzinie działań i teorii artystycznych dominującym problemem był wówczas ${ }^{5}$ temat tzw. końca sztuki i to wobec niego musiała określić się hermeneutyka filozoficzna. Intencją Gadamera było „stawienie czoła zaistniałej sytuacji”, a jednym ze sposobów realizacji takiej postawy był powrót do mitu. Jak zauważa Alina Motycka: „Przyjmując postawę twórczą $\mathrm{w}$ dobie kryzysu naukowego, uczony - w sposób raczej nieuświadomiony i niezamierzony - nawiązuje do kulturowo starych, a nawet przekraczających wzorce danej kultury postaw będących dorobkiem ogólnoludzkim"7 . Dokonuje się tu specyficzne odwrócenie w stronę przeszłości, powrót do źródeł, który badaczka w toku wywodów nazywa „postawą regresywną". Można powiedzieć, że w przypadku Gadamera tło intelektualne i nastroje panujące w czasie pracy nad własną koncepcją filozoficzną sprzyjały takiej właśnie postawie. Wspomniany powrót do mitu był jednak świadomy i programowy. Zgodnie z podstawowymi założeniami hermeneutyki Gadamera głos oddano tu Łzw. doświadczeniom źródłowym: estetycznym, religijnym, codziennym oraz związanym z różnoraką recepcją mitu. Na potwierdzenie tych słów można przytoczyć myśli filozofa zamieszczone w jego mało znanym, lecz doniosłym dla poruszanego tu tematu artykule, zatytułowanym Mythos und Vernunft. Gadamer poddaje w nim m.in. rewizji dla wielu oczywistą opozycję logos-mit. Jak pisze, charakterystyczna jest ona dla myślenia naukowego, w którym „mit jest pomyślany jako

${ }^{3}$ Lilianna Bieszczad, Kryzys pojęcia sztuki (Kraków: Wydawnictwo Uniwersytetu Jagiellońskiego, 2003), 7.

${ }^{4}$ Por.: Reinhart Koselleck, Kritik und Kreise (Frankfurt am Main: Suhrkamp, 1973) oraz tegoż, Vergangende Zukunft (Frankfurt am Main: Suhrkamp, 1979).

${ }_{5}$ Patrz np. Stefan Morawski, Zmierzch estetyki - rzekomy czy autentyczny? (Warszawa: Wydawnictwo Czytelnik, 1987).

${ }^{6}$ Hans-Georg Gadamer, „Koniec sztuki?”, w: Hans-Georg Gadamer, Dziedzictwo Europy, przeł. Andrzej Przyłębski (Warszawa: Aletheia, 1992), 41.

7 Bieszczad, „Kryzys pojęcia sztuki”, 7. 
pojęcie przeciwstawne $\mathrm{w}$ stosunku do racjonalnego tłumaczenia świata" $^{\prime \prime}$. Kontynuując tę myśl, filozof charakteryzuje naukowy obraz świata jako rezygnację z jego mitycznego ujęcia, zgodnie z czym mit jako doświadczenie, które nie może zostać zweryfikowane, został usunięty w obszar niezobowiązującej fantazji, gdzie podobnie jak efekty wyobraźni nie mógł sobie rościć prawa do prawdy. W przeciwieństwie do wymogów racjonalności Gadamer uważa, że mitu nie wolno uważać za bajanie i oszustwo, ale rodzaj świadectwa prawdom. Nawiązując do Platona, który łączył tradycję filozoficzną z religijna, stosując w swoich pismach mity filozoficzne, autor Prawdy i metody przedstawia jego dzieła jako przykład tego, jak stare prawdy i nowe spojrzenie mogą ze sobą koegzystować, stając się jednym. Powołuje się także na dorobek Ernsta Cassirera i jego Filozofie form symbolicznych, który to myśliciel, jak pisze, utorował krytycznej filozofii drogę do uznania pozanaukowych form, jakimi są mity. Uważam, że można zasadnie twierdzić, że w sposób szczególny dotyczą one także tożsamości artysty czy uczestnika sytuacji artystycznych. W ujęciu hermeneutycznym charakteryzują się one tym, że definiuje je charakterystyczny motyw nieciągłości: irracjonalnego "skoku” w akcie twórczym czy „zawieszenia” racjonalności w procesie uczestniczenia. Sprawiają one, że tytułowy kryzys zdaje się dotyczyć nie tylko hermeneutyki jako dyscypliny, ale także tzw. hermeneutycznej tożsamości. Uważam, że wpisanie tak ujętych tożsamości w konkretne mity o Narcyzie i Prometeuszu pogłębia rozumienie podmiotowości hermeneutycznej i obrazuje, w jaki sposób dotyczący jej kryzys trzeba rozumieć jako przemijający, a reprezentujące go zerwania jako tymczasowe, a nie prowadzące do wewnętrznego rozpadu.

\section{Możliwe sposoby ujęcia mitu}

To, czym jest mit, można ująć na co najmniej kilka sposobów. Za Lauri Hanko można wyróżnić następujące sposoby jego rozumienia. Mit może być: kategorią poznawcza, formą symbolicznej ekspresji, projekcją podświadomości, czynnikiem integrującym i regulującym zachowania, legitymizacją struktur społecznych, rodzajem komunikacji religijnej, jej kategorią lub środkiem, obiektem strukturalnego badania'. Wydaje się, że w filozofii Gadamera mit występuje co najmniej w kilku znaczeniach.

1. Po pierwsze mit ujęty jest w pismach Gadamera jako tradycyjny przekaz będący przedmiotem mitologii, nad którym refleksja pomaga

${ }^{8}$ Hans-Georg Gadamer, „Mythos und Vernunft”, w: Hans-Georg Gadamer, Kleine Schriften IV (Tübingen: J.C.B. Mohr (Paul Siebeck), 1977), 48.

9 Szerzej o tym w: Hanko Lauri, The Problem of Defining Myth (Helsinki: Finnish Society for the Study of Comparative Religion in Helsinki, 1972). 
w pogłębieniu wiedzy o człowieku. Filozof pisze: „, [...] to raczej mity nas objaśniają. W rzeczy samej to one, gdziekolwiek przemawiają są tym, co autentycznie góruje nad wszystkim innym, są zbiornikiem wszelkiej wiedzy, czymś, co przy całym mroku, który nas otacza, mówi do nas prosto i pouczająco" 10 .

2. Po drugie mit jest ważnym elementem myśli filozoficznej, zarówno starożytnej (np. myśl orficko-pitagorejska, filozofia Platona), jak i współczesnej (Cassirer), pod której wpływem pozostaje Gadamer.

3. Po trzecie mit może być rozumiany jako to, co jest zrozumiałe przez wszystkich, czyli stanowi kategorię poznawcza, która spełnia także rolę integrującą. Potwierdzenie możemy znaleźć w następującej wypowiedzi Gadamera: „Mit znaczy tu tylko: to, co się opowiada i to opowiada tak, że przemawia ono do nas tak bardzo, iż niepodobna podawać tego w wątpliwość. Mit to coś, co można opowiadać tak, że nikt nie postawił sobie nawet pytania o jego prawdziwość. Jest on prawdą łączącą wszystkich, prawda, w której się wszyscy rozumieją"11. Mit przy takim podejściu można także traktować jako zawartą $\mathrm{w}$ języku dyspozycję, która odsyła nas do wciąż podejmowanej tradycji. Mity, możliwe do wyodrębnienia narracje, byłyby odzwierciedleniem nieświadomego materiału nagromadzonego przez wieki, które pozwalają nam także odkryć zawartą w języku prawdę o nas samych.

4. Po czwarte mit może być ujęty jako pewna struktura obrazowa, w której realizują się postulaty odczytywania hermeneutyki w ramach tzw. iconic turn. Ten sposób interpretacji wypływa przede wszystkim z pracy komentatorów Gadamera, np. Fellmanna.

\section{Próba wpisania hermeneutycznej koncepcji artysty w mit o Narcyzie}

Czytając Aktualność piękna Gadamera, natrafiamy na intrygujące zdanie: „Kto stworzył dzieło sztuki, stoi w istocie przed dziełem swych rąk nie inaczej niż każdy inny"12. Stwierdzenie to charakteryzuje twórcę i mówi o jego relacji wobec dzieła. Relacja ta, jak poucza filozof, w niczym go nie wyróżnia spośród wszystkich innych ludzi, którzy obcują z jego dziełem. Dlaczego? Odpowiedź na to pytanie przenosi nas przede wszystkim w obszar aktu twórczego. Zawiera on elementy, które sprawiaja że sytuacja artysty jawi się $w$ hermeneutyce tak specyficznie. Można powiedzieć, że akt twórczy zawiera w sobie elementy nieświadome,

${ }^{10}$ Gadamer, „Problem dziejów w najnowszej filozofii niemieckiej”, 34.

11 Gadamer, „Koniec sztuki?”, 43.

12 Hans-Georg Gadamer, Aktualność piękna, przeł. Krystyna Krzemieniowa (Warszawa: Oficyna Naukowa, 1993), 45. 
których nie sposób przewidzieć czy zaplanować. Gadamer mówi o tym zjawisku jako o "skoku”: „Między planowaniem i wykonaniem mamy do czynienia ze skokiem. [...] Ten skok wyróżnia dzieło sztuki" ${ }^{13}$. Filozof pozostaje $\mathrm{w}$ tym stwierdzeniu bliski doświadczeniom artystów. Powołajmy się na korespondujący z nim zapis artysty. Józef Czapski - malarz i pisarz - w swojej książce zatytułowanej Patrzac, w rozdziale O skokach i locie zawarł opis doświadczenia aktu twórczego i przeprowadził jego analizę (wykorzystując właśnie pojęcie skoku) w odniesieniu do takich twórców, jak: Claude Monet, Henri Matisse, Paul Cézanne, uwiarygodniając je własnym, artystycznym doświadczeniem. Pojęcie „skoku” urasta do rangi ontologicznego wyróżnika dzieła jako takiego. Jest ono wiarygodne, jeśli powstało kierowane „musem wewnętrznym”, kiedy twórca działa pod wpływem siły, której nie umie się oprzeć. W charakterystyce "skoku” zawiera się również pewne zaprzeczenie dotychczasowym doświadczeniom - tym zdobytym w pracy twórczej, jak i dotychczasowym przeświadczeniom i poglądom. Według analizy Czapskiego np. Cézanne staje się sławny nie dzięki realizującym akademickie reguły obrazom, lecz z uwagi na prace późniejsze, zrywające z tak rozumianą poprawnością. Pomimo doskonałej znajomości natury pracy - analitycznej, rozumowej - to niespodziewanie ryzyko, "rzucenie się w przepaść”, „niebezpieczny lot”, co do którego nie wiadomo, czy nie skończy się upadkiem, stanowi podstawową wartość, konstytuującą powstające dzieła.

Gadamer mniej odnosi się do konkretnych przykładów, lecz przenosi wspomnianą problematykę $\mathrm{w}$ sferę rozważań estetycznych wraz z problemem dla tematu naszych rozważań najistotniejszym, tj. brakiem bezpośredniości w relacji artysta-dzieło. Gadamer sygnalizuje ową cechę (określmy ją precyzyjniej jako odstęp czy dystans pomiędzy świadomymi działaniami twórczymi a ich efektem - dziełem), wprowadzając wspomniane pojęcie skoku. Uwyraźnia w ten sposób irracjonalność, z którą mamy do czynienia w procesie twórczym. Wydaje się, że „skok" można w związku z tym rozpatrywać jako funkcję nieświadomości. Irracjonalność czy przywołana nieświadomość sprawiają że świadomość twórcy nie przesądza ostatecznie o konstytucji dzieła i w rezultacie stanowi ono "coś więcej” niż sumę zdolności swojego twórcy. Z książki Gadamera zatytułowanej Aktualność piękna wiemy, że z tego powodu autor nadaje oddzielną nazwę tego typu pracom, określając je mianem wytworu. Definiuje go następująco:

„Wytwór" nie jest przede wszystkim czymś, o czym można sądzić, że zostało zrobione $\mathrm{w}$ sposób zamierzony [co wciąż jeszcze zwykło się łączyć z pojęciem dzieła]. Akt twórczy, paradoksalnie, zamiast zbliżać 
artystę i dzieło, wyobcowuje twórcę poprzez powyżej przedstawioną logikę działania. Jest więc on zaledwie współgrającym, kimś, kto w medium gry wchodzi $\mathrm{w}$ relację $\mathrm{z}$ dziełem, a poprzez nie $\mathrm{z}$ równorzędnymi sobie odbiorcami. Z takiego opisu wynika także dalsza charakterystyka dzieła - nie daje się ono sprowadzić do sumy przeżyć artysty. Nie mamy tu do czynienia z prostym odwzorowaniem: idea dzieła w umyśle artysty-dzieło. Transformacja treści psychicznych jest tak daleko idąca, że relacja ja-,, własne” dzieło nie może być w ogóle brana pod uwagę. Artysta bierze tylko udział w "grze artystycznej", niejako wchodząc w role, role nietotalne. Gdyby było odwrotnie, oznaczałoby to zerwanie ciągłości procesu bycia z sobą i zupełne utożsamienie się $\mathrm{z}$ nową rolą ${ }^{14}$.

W dosłownym sensie wszelkie obcowanie z dziełem jest więc za sprawą jego struktury ontologicznej jakimś innym, niecodziennym zachowaniem, gdzie autor staje wobec niego tak jak pozostali - jako ,,inny”.

Gdzie w stosunku przeprowadzonej powyżej analizy można poszukiwać analogii do mitu? Kim był Narcyz, wiemy dzięki Metamorfozom Owidiusza, powstałym pomiędzy II a VIII rokiem naszej ery. Zawarta tam historia opowiada o losach młodzieńca, który nieszczęśliwie zakochał się we własnym odbiciu. Relacja, w której uczestniczył Narcyz, to zgodnie z tradycyjnym ujęciem relacja ja-ja. Naszym bohaterem jest jednak artysta - jak odnaleźć go w micie o Narcyzie? Czy można powiedzieć, że dzieło i jego sens jest bezpośrednią pochodną świadomości autora? Że zostało ono stworzone dzięki planowemu przeniesieniu treści jego świadomości, a tym samym, odczytując je, w istocie docieramy do głównego bohatera, którym jest on sam? Taka interpretacja byłaby „narcystyczna" w pierwszym rozumieniu terminu, które w naszej kulturze współczesnej najsilniej zaistniało wykreowane przez psychoanalizę, gdzie Narcyza uczyniono symbolem zaburzeń psychicznych zwanych narcyzmem, w których dochodzi - mówiąc językiem Freuda - do skierowania libido ku wnętrzu, skutkiem czego obiektem pożądania staje się własne ego. Taka wykładnia mitu o Narcyzie przedostała się zarówno do psychologii, jak i seksuologii, dominuje również w myśleniu potocznym. Lokowałaby ona autora i jego dzieło w obszarze „wiernego odzwierciedlenia".

Przedstawiona powyżej analiza pokazuje jednak, że w hermeneutyce Gadamera rzecz wygląda odmiennie. Dzieło wykazuje się samodzielnością wobec artysty. Można powiedzieć, że ten nie rozpoznaje się w dziele, a nawet „ignoruje siebie jako źródło odbicia"15. Manfred

14 Franciszek Chmielowski, Sztuka, sens, hermeneutyka (Kraków: Wydawnictwo Uniwersytetu Jagiellońskiego, 1993), 77.

15 Julia Kristeva, „Narcyz. Nowe szaleństwo”, przeł. Kajetan M. Jaksender, Mêlée 2-3 (2008): 40. 
Frank w książce Świadomość siebie i poznanie siebie posługuje się w pewnym miejscu figurą Narcyza. Pisze: „,[...] kiedy Narcyz, spoglądając marzycielsko na swoje lustrzane odbicie w źródlanej wodzie, wykrzykuje w zachwycie: »O! Jakiż jesteś piękny! «, to bynajmniej nie musi tego odnosić do samego siebie ja k o siebie" ${ }^{\prime \prime 16}$. Pomimo że postronny mógłby stwierdzić: „Narcyz w i e r z y, że to on sam jest piękny"17, z perspektywy bohatera mitu pewności brakuje. Dopiero osoba z zewnątrz, którą w micie symbolizuje Echo, jest w stanie potwierdzić tożsamość odbitego i odbicia. Wydaje się, że sytuacja artysty w zrekonstruowanym powyżej opisie myśli Gadamera jest podobna. Tylko osoba z zewnątrz - interpretator, krytyk lub widz - jest w stanie na podstawie analiz odnaleźć elementy, które wpłynęły na kształtowanie się procesu twórczego, lub np. jego kontekst kulturowy, którego artysta nie jest do końca świadom. Jak już powiedzieliśmy, dzieło ma w swojej konstrukcji elementy, które wyobcowują je w stosunku do swojego twórcy. Dobrze zdają sobie z tego sprawę artyści, często rozstając się ze swoją pracą w symbolicznym geście podpisu. Jak zauważa, analizując historię sztuki, Victor Stoichita w Ustanowieniu obrazu, świadomość postawienia się artysty w stosunku do dzieła „w trzeciej osobie” była powszechna zwłaszcza w XVI wieku. Malarze zamiast mówić wówczas bezpośrednio: „to ja maluję", wypowiadali się $\mathrm{w}$ trzeciej osobie. $\mathrm{W}$ zamian portretowania samych siebie, chętnie odwoływali się właśnie do postaci mitycznych, mówiąc: „ja to kto inny", stając niejako pomiędzy ",ja” a „on”. To tzw. mitologizowany scenariusz tworzenia, gdzie bohaterami stawali się patroni malowania, np. święty Łukasz czy Apelles. Jak podsumowuje Stoichita, maski, które przybiera rzeczywisty autor, są równoznaczne z odwołaniem się do „malarza najlepszego rodzaju” - to już nie twórca maluje, lecz ukazany w sposób symboliczny patron prowadzi jego rękę. Czy może to być odzwierciedleniem świadomości zaistniałej już w starożytności, która każe w sztuce widzieć efekt „boskiego szału” i nie przypisywać autorstwa osobie artysty, lecz siłom tkwiącym poza nim? Czy opisany przez Gadamera „skok” określający logikę aktu twórczego i przypisujący go nieświadomości jest pochodną tej samej intuicji? Nie będę tu podawać decydującej odpowiedzi, pozostawiając dociekania historykom sztuki.

16 Manfred Frank, Świadomość siebie i poznanie siebie, przeł. Zbigniew Zwoliński (Warszawa: Oficyna Naukowa, 2002), 145.

17 Tamże. 


\section{Próba wpisania hermeneutycznej koncepcji uczestnika w mit o Prometeuszu}

Kolejną postacią mityczna, często przywoływaną w kontekście twórczości artystycznej, jest Prometeusz. Mit o Prometeuszu należy do najbardziej rozpowszechnionych w naszej kulturze. Każdy zna postać tytana, który według przekazów miał stworzyć człowieka, a później przynieść mu z niebios ogień. Sam Gadamer poświęca mu wiele uwagi w oddzielnym, poświęconym temu zagadnieniu artykule pt. Prometeusz $i$ tragedia kultury. Filozof zwraca naszą uwagę na wyróżnione tropy interpretacyjne. Podstawowym jest łączenie tytana $\mathrm{z}$ kulturą. $\mathrm{W}$ przedstawionym odczytaniu Prometeusz staje się symbolem człowieka. Jak pisze filozof: „Prometeusz staje się symbolem człowieka wydanego na pastwę własnego sumienia, symbolem tragedii świadomości"18. Stajemy się mu bliscy, ilekroć przychodzi nam zmagać się z „wszechmocą wyobraźni” przeciwstawionej "bezsile rzeczywistości”. Jego losy uwidaczniają tę walkę. Przeciwstawiając się bogom, wykradając ogień, podjął on stwórcze dzieło. Zamysł powiódł się, lecz bohater płaci za niego cierpieniem, co stanowi symbol tragedii kultury. Przywołując ten mit, chciałabym skupić się na wymowie wybranego symbolu, jakim jest ogień. To on jest przyczyną wędrówki tytana do niebiańskich spichlerzy i bezpośrednim powodem jego cierpienia. Gdyby nie ogień, człowiek błąkałby się po ziemi bezradny i bezbronny. Odkąd otrzymaliśmy ów dar Prometeusza, mamy umiejętność radzenia sobie na ziemi. Śledząc wyprawę bohatera po ogień, zauważamy, że nie jest to pierwsza tego typu wędrówka. Po raz pierwszy tytan udał się tam przed stworzeniem człowieka. Wykradł wówczas iskry z rydwanu słońca, aby z nich uformować duszę człowieka. Powtórne wykradzenie ognia i obdarzenie nim ludzi to $\mathrm{w}$ gruncie rzeczy - jak to ujmuje Jan Parandowski - "rozbudzenie ducha" ${ }^{19}$, a więc aktywizacja obecnego już pierwiastka. W konsekwencji panowanie nad światem byłoby więc tu możliwe dzięki pokrewieństwu boskiej natury człowieka i daru. Owo podobieństwo co do istoty, dzięki któremu bierzemy udział w tym, na co już jesteśmy ",a priori wrażliwi" - ta interpretacja przetrwała, jak sądzę, w języku i pozwala nam na głębsze odczytanie symbolu, jakim jest człowiek Prometeusza, tj. jako archetypicznego przedstawienia człowieka pojawiającego się w późniejszej myśli filozoficznej, a zwłaszcza jego cechy, jaką jest pierwotna dyspozycja do udziału w kulturze.

18 Hans-Georg Gadamer, „Prometeusz i tragedia kultury”, przeł. Małgorzata Łukasiewicz, w: Hans-Georg Gadamer, Rozum, stowo, dzieje (Warszawa: Państwowy Instytut Wydawniczy, 2000), 196.

${ }_{19}$ Jan Parandowski, Mitologia (Warszawa: Czytelnik, 1960), 53 
Omawiając figurę uczestnika-odbiorcy, można spróbować wyróżnić etapy drogi, którą przebywa, obcując z wartościami, oraz poszukiwać analogii pomiędzy nią a najistotniejszymi elementami mitu o Prometeuszu ${ }^{20}$.

Pierwszym z jej elementów jest apel. Gadamer pisze: „W dziele sztuki stykamy się z czymś bliskim, a jednocześnie to zetknięcie w zagadkowy sposób wstrząsa nami i burzy zwyczajność. W radosnej i straszliwej grozie dzieło sztuki oznajmia: To jesteś ty - ale mówi także: Musisz zmienić swoje życie" ${ }^{21}$. Słowa te obrazują przede wszystkim relację, w której znajduje się zagadnięty podmiot. Konsekwencją przyjęcia apelu, wyrwania z codzienności jest fakt, że podmiot staje w relacji wobec dzieła, a na jego apel musi udzielić odpowiedzi z głębi siebie. Akt ten umiejscawia podmiot po stronie wartości i ustanawia relację ja-ty.

W kroku drugim podmiot, korzystając ze swojej wolności, odpowiada na wezwanie wartości. Jego odpowiedź jest obciążona ryzykiem wygranej lub przegranej i wymaga oddania się, wsłuchania, przyzwolenia na to, by wartości go ogarnęły. „Grający ulega urokowi gry, który leży właśnie w ryzyku” ${ }^{22}$ - twierdzi filozof. Propozycja Gadamera dobitnie pokazuje ryzyko wdania się w doświadczenie estetyczne. Pierwotnie jawi się ono jako element atrakcyjny - grę zawsze można powtórzyć, przystąpić do niej kolejny raz. Sytuacja ta jest nazwana obszarem odpowiedzialności ludycznej w przeciwieństwie do życiowej. Istnieją jednak w wykładni Gadamera elementy, które - jak sadzę - pozwalają na rozpatrzenie konsekwencji podjęcia gry także w wymiarze naszego praktycznego życia, co zupełnie zmienia jej stawkę. Wówczas podjęcie jej, jak to ujmuje Chmielowski, „oznacza, że musi on [»gracz«-M.B.] zamienić cele swojego zachowania w zadania samej gry"23. Gracz podporządkowuje się więc przedmiotowi gry, niejako rezygnuje świadomie z siebie jako całości egzystencji. Możliwy racjonalny rachunek poprzedzający podjęcie gry zostaje w jej trakcie „zawieszony”, a rozum pozwala całkowicie podporządkować się przedmiotowi. Stanowi to bezpośrednią aluzję do mistycznego wsłuchania. Czy konsekwencją tego jest tylko odprężenie, odciążenie od życiowych problemów, pokrewne doświadczeniu zabawy? Wydaje się, że autor Prawdy $i$ metody przedstawia tę kwestię w sposób na tyle otwarty, że pozwala ona na interpretację w kategoriach

20 Szerzej o tym: Malina Barcikowska, „Uczestnik sztuki jako świadek w hermeneutyce H.-G. Gadamera", Zeszyty Naukowe Towarzystwa Doktorantów UJ. Nauki Humanistyczne 2, 1 (2011).

${ }^{21}$ Hans-Georg Gadamer, „Estetyka i hermeneutyka”, przeł. Małgorzata Łukasiewicz, w: Hans-Georg Gadamer, Rozum, stowo, dzieje (Warszawa: PIW 2000), 141.

${ }^{22}$ Chmielowski, Sztuka, sens hermeneutyka, 51.

23 Tamże. 
filozofii praktycznej - jako apel o kształtowanie postawy. Gra może być więc odczytana w szerszej perspektywie - jako gra o sens życia.

Ostatnim etapem jest wspomniane przyjęcie postawy życiowej jako rodzaju „świadectwa”. Dzięki temu dochodzi po pierwsze do jej realizacji, a po drugie do rozpoznania tożsamości nosiciela wartości. Przywołany proces może się dokonać dzięki temu, że podmiot jest wrażliwy na wartości niejako a priori.

Powtórne wykradzenie ognia przez Prometeusza i obdarzenie nim ludzi to w gruncie rzeczy "rozbudzenie ducha”, a więc aktywizacja pierwiastka obecnego już w człowieku. W konsekwencji panowanie człowieka nad światem lub podjęcie apelu i danie świadectwa w odpowiedzi na apel byłyby możliwe dzięki pokrewieństwu naszej natury i otrzymanego przez nas daru - ognia. Owo pokrewieństwo co do istoty powoduje, że zdolni jesteśmy do udziału w kulturze, na którą jesteśmy już a priori wrażliwi.

\section{Tożsamość performera a hermeneutyka}

Wydaje się, że próbując opisać tożsamość hermeneutyczną w ogóle i czyniąc odniesienia do sztuki, najwyraźniejszych podobieństw można poszukiwać w performansie. „Nie wydaje się, aby odpowiedniki leżały jak na dłoni" ${ }^{24}$ - pisał Stefan Morawski w przedmowie do polskiego wydania Aktualności piękna jeszcze w latach 90., podkreślając efemeryczność tej formy sztuki w przeciwieństwie do wagi "wytworu” w koncepcji hermeneutycznej, jej ludyczność w przeciwieństwie do konieczności powagi czy brak ambicji poznawczych reprezentujących ją artystów, którzy nie starali się jego zdaniem dotrzeć do tzw. prawdy istnienia. Podobieństw do hermeneutycznej teorii sztuki można według komentatora poszukiwać jedynie pomiędzy najambitniejszymi przykładami performansów, np. twórczością Juliana Becka, Judith Maliny czy Johna Cage’a. Tymczasem na Gadamera powołują się np. współcześni teoretycy teatru, aby wytłumaczyć, dlaczego aktualnie zmierza on w stronę zwaną zwrotem performatywnym, i wskazać na jego tzw. eksperymentalną genealogię, która kształt dzisiejszego teatru wywodzi bezpośrednio z ruchu, który prowadził „od futurystów, poprzez dadaizm i surrealizm, do happeningów i dalej do współczesnych performansów ${ }^{\prime 25}$ kształtujących paradygmat relacji twórca-wykonawca-tekst-scena-widz. Stąd, analizując najnowszą literaturę dotyczącą tej bardzo dynamicznie rozwijającej się problematyki, można pokazać wyraźne zależności między współczes-

${ }^{24}$ Gadamer, Aktualność piękna, 79.

${ }^{25}$ Marvin Carlson, Performans, przeł. Edyta Kubikowska (Warszawa: Wydawnictwo Naukowe PWN, 2007), 136. 
nymi praktykami artystycznymi a hermeneutyka, wyraźniejsze niż to miało miejsce jeszcze w ubiegłym wieku. Szczególnie pouczające są analizy przedstawione przez Marvina Carlsona w pracy Performans.

Tytułowy performans ma wiele obliczy. Sztuki performatywne definiujemy najogólniej jako te, które polegają na wyeksponowaniu czynów przed publicznością, w znaczeniu węższym zaliczamy do nich teatr, taniec, muzykę i właśnie performans. W znaczeniu szerszym obejmą one wszystkie czynności, także tzw. umiejętności i związaną z nimi skuteczność. Oprócz definiowania dyscypliny w sposób szerszy i węższy można traktować go jako metaforę współczesnej kultury, a nawet jej paradygmatyczne ujęcie. Sama hermeneutyka jest przywoływana w omawianej pozycji kilkukrotnie, choć głównie w odwołaniu do jej komentatorów. Warto zwrócić uwagę na dwa fragmenty, w których nawiązania teorii performansu do interesującej nas hermeneutyki wskazują na obszary wspólnego rozumienia wyróżnionych zagadnień.

Pierwszy dotyczy Joela Weinsheimera. Carlson przytoczył następujący fragment jego pracy Gadamer's Hermeneutics: a Reading of 'Truth and Method': „Performance nie jest czymś dodatkowym, przypadkowym czy zbędnym, czymś, co daje się odróżnić od właściwej sztuki. Właściwa sztuka istnieje tylko i wyłącznie, kiedy się ją gra. Performans powołuje sztukę do życia, a granie sztuki jest samą sztuką. [...] Nabiera życia w przedstawieniu oraz w całej przypadkowości i szczegółowości sytuacji, w których się dzieje"26.

Autor odnosi się do wartościowania, które mogłoby ocenić performans jako "dodatkowy", "przypadkowy", "zbędny" z tego powodu, że jego istnienie jest chwilowe oraz zmienia się w czasie i przestrzeni. Przywołanie kluczowego dla hermeneutyki pojęcia "gry" powoduje usankcjonowanie wypunktowanej również przez Morawskiego „efemeryczności" i podkreślenie wagi zdarzenia. Analizując przywołaną wypowiedź, Carlson podkreśla jednak, że przeniesienie punktu ciężkości z pojęcia „wytworu” na pojęcie "gry” obowiązuje w każdym typie sztuki, która pod uwagę bierze widza i zmieniający się kontekst jej recepcji. Co to oznacza dla współczesnego dzieła sztuki? Trzymając się klasycznego dyskursu, trzeba powiedzieć, że pożądana niegdyś przez artystów i krytyków niezmienna istota dzieła musi ustąpić tzw. zdarzeniu sztuki. Historia performansu pokazuje, że nawet $\mathrm{w}$ tej dziedzinie nie był to proces łatwy i przyjmowany bez oporów. Ankieta przeprowadzona $\mathrm{w}$ latach 80 . w jednym $\mathrm{z}$ wiodących na świecie magazynów artystycznych "Artforum” postawiła przed samymi artystami problem powodu zmian. Opowiadając na pytanie "Jakie zmiany w estetyce, w punktach ciężkości i w innych sferach spowodowały nietrwałość i specyfikę sztuki performansu?", wskazywano na przeniesienie punktu ciężkości z galerii

\footnotetext{
${ }^{26}$ Tamże, 224.
} 
na „uprawianie” sztuki i jej „doświadczanie”. Proces ten połączono także ze zmianą stosunku do widowni, od której nie oczekiwano już, że będzie, jak pisał Jon Erickson, własną projekcją artystów, która jednakowo i poprawnie odbiera artystyczne zamiary twórców. Łatwo zauważyć, że wymienione doświadczenia artystów można odnaleźć także w tekstach Gadamera - w symbolicznym „wyjściu poza ramy” koncepcji doświadczenia hermeneutycznego oraz uczestnika.

Drugim interesującym mnie momentem zarysowanej w publikacji analogii jest zagadnienie widza/uczestnika, definiowanego przez pryzmat tzw. czynnej współpracy. Szczególną rolę odgrywa tu konstytuowana podczas przedstawień wspólnota widzów, którzy traktują miejsce wystawienia performansu jako tradycyjnie ujęte miejsce podróży w celu grupowego doświadczania przeżyć. Szczególnie interesujące z punktu widzenia hermeneutyki są przywoływane przez Carlsona rozważania Victora Turnera. Choć nie pada w nich bezpośrednio nazwisko Gadamera, ich początkiem było zbieżne w czasie z powstaniem koncepcji autora Prawdy $i$ metody zainteresowanie tzw. kontekstem społecznym oraz zjawiskiem zabawy, które spowodowało także rozwój analiz dotyczących teatru oraz dramatu. Podobnie jak dla niemieckiego hermeneuty źródłową pozycją była i w tym przypadku praca Huizingi Homo ludens, ale także Gry i ludzie Rogera Caillois. Najistotniejszą według mnie kwestia, która może inspirować także rozwój pokrewnych zainteresowań hermeneutów, jest zagadnienie rozwijania i wzmacniania poczucia wspólnoty - cechą bliskiego związku zabawy z rytuałem jest tzw. scalenie. Choć zabawa może być także „zabawą wywrotową", sprzyjać zachowaniom destrukcyjnym i chaotycznym, być bliska karnawałowi - co opisywał np. Michaił Bachtin, wspólne im jest docenienie obszarów nazwanych przez Turnera działaniami liminalnymi lub liminoidalnymi. Polegają one na tym, że pozwalają członkom danej grupy „myśleć o tym, jak myślą, w zdaniach, które nie zawierają się w kodach kulturowych, tylko o nich traktują"27. W tym obszarze "poza ramami" mają szansę wyłonić się nowe symbole, wzorce, modele. Podczas takiej zabawy widzowie/ /uczestnicy przeżywają stan oszołomienia polegający na chwilowym utraceniu kontroli oraz poczucia sensu. Jest to warunkiem wyzwolenia. Turner używa w tym miejscu słowa „przepływ” (za psychologami Johnem MacAlloonem, Mihalym Csikszentmihalyim) i jest ono stosowane dla nazwania doświadczenia, które polega na poczuciu utraty tożsamości czy celowości działań oraz dotyczy zarówno doświadczenia zabawy, jak i doświadczenia religijnego. Przepływ można więc ująć w kategoriach kryzysu lub - jak to czyni Turner - "dramatu społecznego". Jego uniwersalna struktura jest następująca. Składa się on z czterech etapów:

27 Victor Turner, The Ritual Process: Structure and Anti-Structure (Chicago: University of Chicago Press, 1969), 22. 
1) naruszenie akceptowalnych i ustalonych norm, 2) narastający kryzys, 3) przywracanie równowagi dzięki zastosowaniu mechanizmów zapobiegających kryzysowi, 4) ponowna integracja, która zmienia pierwotną sytuację. Jest to, jak sądzę z, punktu widzenia próby charakterystyki hermeneutyki i opisanych przez nią tożsamości jako bezpośrednio związanych z sytuacją kryzysową najbardziej inspirujący moment rozważań.

Użyte przez Morawskiego określenie „efemeryczny” (gr. ephémeros - jednodniowy) akcentowało postawienie naprzeciw siebie dwu odmiennych koncepcji dzieła sztuki, które dzieli przede wszystkim sposób podejścia do jego istoty. Jak zauważa Władysław Stróżewski, o istotę można pytać na kilka sposobów. Pytanie ontologiczne postawi przed nami problem tego, ",co istotne w rzeczy", a odpowiedź powinna wskazać to „coś", co decyduje o tym, czym dana rzecz jest. Analogiczne pytanie zadane $\mathrm{z}$ punktu widzenia epistemologii kieruje nas ku zagadnieniom związanym z naszym poznaniem, które stara się dotrzeć do prawdy rzeczy i opiera się na odpowiedniości porządku ontologicznego i porządku poznania - to dzięki niemu możliwe staje się odsłonięcie istoty rzeczy. Zdefiniowanie sztuki jako ulotnej, szybko znikającej czy krótkotrwałej $\mathrm{w}$ tradycyjnym dyskursie uniemożliwia nam zarówno określenie istotowego „co" dzieła sztuki, jak i jego poznanie. Tymczasem performans planowo odrzuca wszelki esencjalizm, opisując się jako „ruch momentów”, a tożsamość performera za Simone de Beauvoir jako "stylizowane powtarzanie aktów" 28 i w tym m.in. upatruje swojej wyjątkowości. Nie przyznaje się przy tym także do emocjonalnych zarzutów o „nonsensowność poszukiwania sensów całości, skoro dany jest jedynie chaotyczny i aleatoryczny strumień zajść jednorazowych i ulotnych jak łątki, pozbawiony wszelkiej logiki"29. W swojej technice upatruje raczej narzędzia do inspirujących analiz działania nie tylko jednostki, ale także społeczeństw i kultur. Podobne wnioski wypływają z definicji performansu zaproponowanej przez Johna MacAloona. Performans, pisze on, to „wydarzenie, podczas którego my jako kultura lub społeczeństwo zastanawiamy się nad sobą i określamy się, dramatyzujemy nasze zbiorowe mity i naszą historię, przedstawiamy się w innych wydaniach i ostatecznie zmieniamy się pod pewnymi względami, a pod pewnymi zostajemy tacy sami" ${ }^{\prime 30}$. Podobnie jak ceremonie obrzędowe, obchody wydarzeń kulturowych, performans zachowuje ważność jako praxis, które definiuje tzw. jaźń społeczeństw.

${ }^{28}$ Grzegorz Sztabiński, „Performatywna koncepcja artysty w sztuce współczesnej", w: Zwrot performatywny w estetyce, red. Lilianna Bieszczad (Kraków: Libron 2013), 35.

${ }^{29}$ Morawski, w: H. G. Gadamer, Aktualność piękna, 79.

${ }^{30}$ Carlson, Performans, 48. 
Rollo May, amerykański psychoanalityk, opisując w latach 90. w książce Błaganie o mit kondycję zachodnich społeczeństw i proponując konkretne rozwiązania terapeutyczne w odpowiedzi na obecne $w$ nich problemy, za najważniejszą ich przyczynę uznał brak mitów, wypartych przez kult materialnego dobrobytu. Mit rozumiał przy tym jako narracyjne wzorce, które nadają egzystencji człowieka znaczenie oraz sens, broniąc go przed wewnętrznym rozpadem. Kształty tożsamości, które można zrekonstruować na podstawie pism Gadamera, uwyraźniają ich kryzysowy wymiar. Wszystkie one obrazują "utratę poczucia zadomowienia” nazywaną tu „skokiem” w przypadku artysty, a „zawieszeniem" w procesie bycia uczestnikiem lub programowym brakiem ciągłości wyrażonej jako „ruch momentów” w „modelowym” opisie bliskiej hermeneutyce tożsamości performera. Doświadczenie będące udziałem każdej z nich odzwierciedla w gruncie rzeczy ten sam model "dramatu społecznego", w którym wpisanie w mit może być rozumiane jako podkreślenie jego ostatniego aktu, czyli ponowna integracja zmieniająca pierwotną sytuację.

Oto artysta przezwycięża wyrażony przez irracjonalny "skok" kryzys dzięki wpisaniu się we wspólnotę innych interpretatorów. Oto podmiot pokonuje ryzykowne "zawieszenie" racjonalnego podejścia poprzez to, że zostaje w nim rozbudzony pokrewny wspólnocie uczestników kultury pierwiastek, dzięki czemu rozpoznaje on swoją tożsamość i pokrewieństwo z nimi.

Jak zauważa Piotr Domeracki, na podstawie prac Gadamera nie można jednoznacznie stwierdzić, czy bezwzględnie uprzywilejowana jest w tej myśli jednostka względem zbiorowości, czy zbiorowość góruje nad jednostką: „w piśmiennictwie Gadamera, jakkolwiek społecznie nastawionym, współistnieją obie tendencje: indywidualistyczna (syngularystyczna) i kolektywistyczna (komunitarystyczna). Trudno nawet powiedzieć, która przeważa"31. Owo napięcie realizuje się już w procesie socjalizacji pojedynczego człowieka. Andrzej Bronk pisze: „W punkcie wyjścia filozofii Gadamera znajduje się konkretny człowiek, zakorzeniony $\mathrm{w}$ świecie i ukształtowany $\mathrm{w}$ rozlicznych procesach socjalizacji i inkulturacji, ze świadomością uformowaną dotychczasowym jego poznaniem i działaniem"32. Ową decydującą przynależność do wspólnoty wyraża się w myśli Gadamera rzecz jasna przede wszystkim w językowym wymiarze naszego bycia. Na potwierdzenie tego przytoczmy sło-

31 Piotr Domeracki, „Między indywidualizmem a kolektywizmem. Rudymenty hermeneutycznej filozofii człowieka", w: Hermeneutyczne dziedzictwo filozofii, red. Mariusz Oziębłowski, Hubert. T. Mikołajczyk (Kraków: Wydawnictwo „Scriptum”, 2006), 211.

32 Andrzej Bronk, „Epistemologiczny charakter filozofii Gadamera”, Studia Filozoficzne 1 (1985): 285. 
wa samego filozofa: „świadomość nigdy nie stoi naprzeciw świata, sięgając - w stanie jakby bezjęzykowym - po narzędzie porozumienia. We wszelkiej wiedzy o nas samych i o świecie jesteśmy już ogarnięci przez język, przez nasz własny język. Wychowujemy się, poznajemy świat, poznajemy ludzi i w końcu poznajemy nas samych, ucząc się mówić"33. Przywołanie mitów jest więc także przywołaniem konkretnego języka tradycji, która wypełnia trzeci z podanych tu sposobów rozumienia mitu: stanowi on kategorię poznawczą, spełniającą rolę integrującą oraz pozwala nam odkryć zawartą w języku prawdę o nas samych. Kluczowy problem części i całości, który stanowi istotę powyższych rozważań, został odzwierciedlony $\mathrm{w}$ figurze patrona hermeneutyki - mitycznego Hermesa. To on jest postacia która mediuje pomiędzy tymi obszarami: teksty bogów stara się przekładać tak, aby były zrozumiane także pozostałym, w swoisty sposób zacierając granicę między nimi i sprawiając, że tak jak u prapoczątków ludzie mogą przebywać z bogami w jednej przestrzeni. Ostatecznie najpełniej wyraża on właśnie język - obecny przede wszystkim jako medium spotkania i porozumienia. Paweł Dybel, określając lokację hermeneutyki, stwierdza, że realizuje się ona w obszarach między „filozofią i doświadczeniem nauk humanistycznych i przyrodniczych, filozofią i sztuką czy filozofią i różnymi formami doświadczenia potocznego" ${ }^{34}$. Być może zadaniem szerszej analizy wykazującej obecność wątków mitycznych w hermeneutyce jest ukazanie funkcji jednoczącej mitów, realizującej się jako bycie specyficznymi „mostami” pomiędzy wymienionymi sferami.

\section{Bibliografia}

Barcikowska Malina. 2011. „Uczestnik sztuki jako świadek w hermeneutyce H. G. Gadamera", Zeszyty Naukowe Towarzystwa Doktorantów UJ. Nauki Humanistyczne 2, 1: 209-217.

Bieszczad Lilianna. 2003. Kryzys pojęcia sztuki. Kraków: Wydawnictwo Uniwersytetu Jagiellońskiego.

Bronk Andrzej. 1985. „Epistemologiczny charakter filozofii Gadamera”, Studia Filozoficzne 1: 37-51.

Carlson Marvin. 2007. Performans, przeł. Edyta Kubikowska. Warszawa: Wydawnictwo Naukowe PWN.

Chmielowski Franciszek. 1993. Sztuka, sens, hermeneutyka. Kraków: Wydawnictwo Uniwersytetu Jagiellońskiego.

${ }^{33}$ Hans-Georg Gadamer, "Człowiek i język”, przeł. Krzysztof Michalski, w: Hans-Georg Gadamer, Rozum, słowo, dzieje (Warszawa: Państwowy Instytut Wydawniczy, 2000), 55.

34 Paweł Dybel, Oblicza hermeneutyki (Kraków: Universitas, 2012), 28. 
Domeracki Piotr. 2006. „Między indywidualizmem a kolektywizmem. Rudymenty hermeneutycznej filozofii człowieka". W: Hermeneutyczne dziedzictwo filozofii. Red. Mariusz Oziębłowski, Hubert. T. Mikołajczyk. 201-222. Kraków: Wydawnictwo „Scriptum”.

Paweł Dybel. 2012. Oblicza hermeneutyki. Kraków: Universitas.

Frank Manfred. 2002. Świadomość siebie i poznanie siebie, przeł. Zbigniew Zwoliński. Warszawa: Oficyna Naukowa.

Gadamer Hans-Georg. 1992. „Koniec sztuki?”, przeł. Andrzej Przyłębski. W: Hans-Georg Gadamer, Dziedzictwo Europy. 41-55. Warszawa: Aletheia.

Gadamer Hans-Georg. 1977. „Mythos und Vernunft”. W: Hans-Georg Gadamer, Kleine Schriften IV. Tübingen: J.C.B. Mohr (Paul Siebeck).

Gadamer Hans-Georg. 1993. Aktualność piękna, przeł. Krystyna Krzemieniowa. Warszawa: Oficyna Naukowa.

Gadamer Hans-Georg. 2000. Rozum, słowo, dzieje, przeł. Małgorzata Łukasiewicz, Krzysztof Michalski. Warszawa: Państwowy Instytut Wydawniczy.

Grondin Jean. 2007. Wprowadzenie do hermeneutyki filozoficznej, przeł. Leszek Łysień. Kraków: Wydawnictwo WAM.

Koselleck Reinhart. 1973. Kritik und Kreise. Frankfurt am Main: Suhrkamp.

Koselleck Reinhart. 1979. Vergangende Zukunft. Frankfurt am Main: Suhrkamp.

Kristeva Julia. 2008. „Narcyz. Nowe szaleństwo”, przeł. Kajetan M. Jaksender. Mêlée 2-3: 37-50.

Lauri Hanko. 1972. The Problem of Defining Myth. Helsinki: Finnish Society for the Study of Comparative Religion in Helsinki.

Parandowski Jan. 1960. Mitologia. Warszawa: Czytelnik.

Stefan Morawski. 1987. Zmierzch estetyki - rzekomy czy autentyczny? Warszawa: Czytelnik.

Sztabiński Grzegorz. 2013. „Performatywna koncepcja artysty w sztuce współczesnej". W: Zwrot performatywny w estetyce. Red. Lilianna Bieszczad. 31-42. Kraków: Libron.

Turner Victor. 1969. The Ritual Process: Structure and Anti-Structure. Chicago: University of Chicago Press.

\section{Streszczenie}

Powstanie hermeneutyki filozoficznej utożsamia się z okresem kryzysu kultury Zachodu. Wstrząs związany z gwałtownym przełomem w sferze wartości był tym, wobec czego także ona musiała się określić. Intencją Gadamera stało się stawienie czoła zaistniałej sytuacji, a jednym ze sposobów realizacji takiej postawy okazał się powrót tzw. doświadczeń źródłowych: estetycznych, religijnych, codziennych oraz mitycznych. W dziedzinie działań i teorii artystycznych pomogły one zmierzyć się z problemem „końca sztuki”. Bezpośrednio lub w sposób bardziej zakryty hermeneutyka wykorzystuje zarówno konkretne mity starożytne, jak i specyficzne znaczenia, jakie można im przypisać także w koncepcjach 
tożsamości, np. artysty czy uczestnika. Swoje odzwierciedlenie znalazło w nich utożsamiane z kryzysem zerwanie ciągłości. Wskazanie na mity jako wiążące prefiguracje pozwala odczytać je jako narracje, które nadają egzystencji człowieka znaczenie oraz sens, broniąc go przed wewnętrznym rozpadem.

Słowa kluczowe: mit, kryzys, tożsamość, sztuka, hermeneutyka, artysta, uczestnik, performans

\section{Summary}

\section{Art, Myth, and the "Crisis Identity" in the Hermeneutics of Hans-Georg Gadamer}

The emergence of philosophical hermeneutics is associated with a period of the Western culture crisis. Hermeneutics had to respond to a shock caused by a sudden shift in the sphere of values. Gadamer's intention was to face the situation and one of the ways to do that was to return to the so-called source experiences aesthetic, religious, ordinary, and mythical. They helped to solve the problem of "the end of art" in the field of artistic actions and theories. Openly, or to some extent discreetly, hermeneutics uses both particular ancient myths and specific meanings that can be ascribed to them also in the concepts of identity of e.g. an artist or a participant. They reflect the discontinuity associated with the crisis. Pointing to myths as binding prefigurations allows interpreting them as narrations that give meaning and reason to human existence, thus defending a person against an internal disintegration.

Keywords: myth, crisis, identity, art, hermeneutics, artist, participant, performance 